\title{
Penerapan Pendekatan Konstruktivis Untuk Meningkatkan Hasil Belajar IPA di Kelas IV SD Negeri 003 Bangkinang Kota
}

\author{
Rusdial Marta \\ Program Studi PGSD FIP Universitas Pahlawan Tuanku Tambusai Bangkinang Riau \\ dial.fredo90@gmail.com
}

\begin{abstract}
ABSTRAK
Permasalahan yang diamati dalam pembelajaran IPA di kelas IV SDN 003 Bangkinang Kota, guru belum sepenuhnya melibatkan siswa secara aktif. Hal ini disebabkan keterbatasan alat peraga dan kurangnya variasi penerapan metode maupun pendekatan pembelajaran, guru lebih cenderung menggunakan pendekatan konvensional. Siswa dalam pembelajaran belum dijadikan subjek belajar, kebanyakan siswa menerima materi yang disampaikan guru berupa hafalan. Hal ini menyebabkan rendahnya hasil belajar yang diperoleh siswa, adapun nilai rata-rata hasil belajar IPA semester I dengan pendekatan dan metode yang biasa digunakan guru mencapai 70 dibawah KKM. Pembelajaran dengan menggunakan kontruktivis dapat meningkatkan hasil belajar siswa. Selain itu, siswa juga menjadi lebih aktif dalam belajar. Hal itu dapat terlaksana karena permasalahan yang diajukan sering mereka temui dalam kehidupan sehari-hari, berakibat siswa termotivasi untuk aktif melakukan percobaan dalam kelompoknya. Dengan menggunakan metode ini, siswa sudah mulai cenderung untuk aktif dalam pembelajaran. Penerapan pendekatan konstruktivis dalam pembelajaran IPA di kelas IV SDN 003 Bangkinang Kota, dapat meningkatkan hasil belajar siswa yang terlihat pada rata-rata hasil belajar pada siklus I yaitu 6,96 meningkat menjadi 7,48 pada siklus II. Dengan demikian pembelajaran IPA dengan penerapan pendekatan konstruktivis dapat meningkatkan hasil belajar siswa di kelas IV SDN 003 Bangkinang Kota pada mata pelalajaran IPA.
\end{abstract}

Kata Kunci: Hasil Belajar, IPA, Kontruktivisme

\section{PENDAHULUAN}

Perkembangan Ilmu Pengetahuan dan Teknologi (IPTEK) yang sangat pesat menuntut dunia pendidikan untuk selalu mengadakan peningkatan dalam pembelajaran. Salah satu cara yang dapat dilakukan untuk meningkatkan pembelajaran adalah dengan mengadakan pembaharuan pendekatan yang digunakan dalam pembelajaran. Pendekatan pembelajaran adalah upaya yang dilakukan untuk membuat siswa terlibat aktif dan berminat dalam mengikuti pembelajaran. Menurut Nasution (2003:53) pendekatan pembelajaran pada hakikatnya adalah "suatu usaha untuk mengembangkan keefektifan pembelajaran". Kenyataan menunjukkan bahwa manusia dalam segala hal selalu berusaha mencari efisien-efisien kerja dengan jalan memilih dan menggunakan suatu cara yang dianggap terbaik untuk mencapai tujuannya. Demikian juga dengan pembelajaran, guru selalu berusaha memilih pendekatan pembelajaran yang tepat dan dipandang lebih efektif daripada pendekatan lain.
Penggunaan pendekatan dalam pembelajaran berpengaruh terhadap hasil belajar yang diperoleh, semakin tepat pendekatan yang digunakan maka hasil yang diperoleh semakin maksimal. Begitu pentingnya pendekatan dalam pembelajaran, sehingga guru dituntut mempunyai pengetahuan dan keterampilan dalam memilih dan menerapkan berbagai pendekatan pembelajaran yang sesuai dengan karakteristik siswa dan materi pembelajaran. Sebagaimana pendapat Maslichah (2006:37) yang menyatakan bahwa "untuk keberhasilan suatu pembelajaran guru perlu mengetahui dengan siapa atau siswa yang bagaimana yang akan dihadapi, tanpa paham tentang siswa yang akan difasilitasi mustahil guru dapat memilih pendekatan pembelajaran yang tepat dan materi pembelajaran yang sesuai".

Salah satu pendekatan yang dapat digunakan untuk meningkatkan hasil belajar adalah pendekatan konstruktivis. Menurut Wina (2006:264) pendekatan konstruktivis adalah "proses membangun atau menyusun pengetahuan baru dalam struktur kognitif siswa berdasarkan pengalaman". Pembelajaran 
dalam pendekatan konstruktivis bukanlah kegiatan memindahkan pengetahuan dari guru ke siswa, melainkan suatu kegiatan yang memungkinkan siswa membangun sendiri pengetahuannya.

Tugas guru dalam pembelajaran
dengan menggunakan
konstruktivis adalah membantu agar siswa mampu membangun pengetahuannya sesuai dengan situasi konkrit, sehingga hasil pembelajaran dapat ditingkatkan. Sebagaimana pendapat Gagne dan Briggs (dalam Wahyudin, 2008:1) menyatakan bahwa "hasil belajar adalah kemampuan yang diperoleh seseorang sesudah mengikuti proses belajar". Hasil belajar siswa dikatakan baik apabila ranah kognitif, afektif, dan psikomotor meningkat. Meningkatnya ketiga aspek ini dapat diamati langsung dalam pembelajaran Ilmu Pengetahuan Alam (IPA), karena aspek pokok dalam pembelajaran IPA menurut Usman (2006:12) adalah "membangkitkan rasa ingin tahu siswa untuk menggali berbagai pengetahuan baru, dan akhirnya dapat mengaplikasikan dalam kehidupan mereka".

Di Sekolah Dasar (SD) pembelajaran IPA terdiri dari empat aspek yakni: makhluk hidup dan proses kehidupannya, benda/materi, sifat dan kegunaannya, energi dan perubahannya, serta bumi dan alam semesta. Keempat aspek ini merupakan fokus tujuan pembelajaran IPA di SD. Menurut Depdiknas (2006:484) pembelajaran IPA bertujuan untuk "menumbuhkan kemampuan berfikir, bekerja dan bersikap ilmiah, serta mengkomunikasikannya sebagai aspek penting kecakapan hidup".

Pada saat ini kemampuan siswa SD untuk menerapkan IPA di lingkungannya sehari-hari tergolong rendah. Untuk meningkatkan kemampuan tersebut, ada beberapa aspek yang dapat diperhatikan guru dalam pembelajaran IPA yang dikemukakan oleh Usman (2006:5) antara lain:

pentingnya memahami bahwa pada saat memulai kegiatan pembelajaran IPA, siswa telah memiliki berbagai konsepsi, pengetahuan yang relevan dengan apa yang mereka pelajari, 2) aktivitas siswa melalui berbagai kegiatan nyata dengan alam menjadi hal utama dalam pembelajaran IPA, 3) bertanya merupakan ciri utama dalam pembelajaran IPA dan memiliki peran penting dalam upaya membangun pengetahuan selama pembelajaran, 4) pembelajaran IPA memberikan kesempatan kepada siswa untuk mengembangkan kemampuan berpikirnya dalam menjelaskan suatu masalah.

\section{METODE PENELITIAN}

Penelitian ini merupakan penelitian tindakan kelas yang dilaksanakan di SD Negeri 003 Bangkinang Kota. Subjek dalam penelitian ini adalah siswa kelas IV SD Negeri 003 Bangkinang Kota, yang berjumlah 40 orang, terdiri dari 23 orang siswa laki-laki dan 17 orang siswa perempuan.

\section{HASIL \& PEMBAHASAN}

\section{Pelaksanaan Siklus I}

Pelaksanaan pembelajaran pada siklus I sesuai dengan apa yang telah direncanakan, yang mana pada siklus I pembelajaran disajikan dalam dua kali pertemuan (5x35menit). Dalam suatu kegiatan pembelajaran siswa dikatakan telah belajar, apabila terjadi proses perubahan perilaku pada diri siswa sebagai hasil dari suatu pengalaman. Pelaksanaan pembelajaran dengan menggunakan pendekatan konstruktivis merupakan proses membangun atau menyusun pengetahuan baru dalam struktur kognitif siswa berdasarkan pengalaman.

Pembelajaran dalam pendekatan konstruktivis bukanlah kegiatan memindahkan pengetahuan dari guru ke siswa, melainkan suatu kegiatan yang memungkinkan siswa membangun sendiri pengetahuannya, artinya Pendekatan konstruktivis menempatkan siswa sebagai subjek belajar. Seluruh aktifitas yang dilakukan siswa dalam pendekatan konstruktivis diarahkan untuk membangun konsep awal siswa terhadap materi dan memahami konsep tersebut salah atau benar setelah mengikuti pembelajaran.

Pembelajaran pada siklus I dilaksanakan sesuai dengan langkah-langkah pendekatan konstruktivis yaitu pengaktifan pengetahuan yang sudah ada, pemerolehan pengetahuan baru, pemahaman pengetahuan, menerapkan pengetahuan dan pengalaman yang diperoleh, refleksi. Pelaksanaan pembelajaran pada siklus satu belum sempurna karena kebiasaan siswa dalam belajar yang terbiasa menerima informasi dari guru sehingga siswa sulit untuk menyesuaikan diri dengan pendekatan konstruktivis yang menuntut keaktifan siswa dalam pembelajaran dengan banyak bertanya sehingga dapat membangun pengetahuan awalnya terhadap materi pembelajaran dan lebih memahami dengan adanya tanggapan dari temannya. 
Sebagaimana pendapat Noraziah (2008) bahwa ciri-ciri pembelajaran dengan pendekatan konstruktivis salah satunya adalah "pengetahuan dikembangkan secara aktif oleh siswa sendiri, tidak diterima secara pasif dari orang sekitarnya. Ini berarti pembelajaran merupakan usaha dari siswa itu sendiri dan bukan dipindahkan dari guru kepada siswa".

Berdasarkan catatan pada lembar observasi dan diskusi peneliti dengan pengamat, penyebab dari masih rendahnya hasil belajar siswa pada siklus I adalah kurangnya kemampuan siswa dalam memberikan tanggapan terhadap presentasi hasil diskusi, sehingga siswa kurang memahami materi yang telah dipelajarinya. Selain itu jumlah siswa yang banyak menyebabkan kegiatan siswa kurang terkontrol oleh guru.

Kegiatan pembelajaran dengan pendekatan konstruktivis terdiri dari 5 tahap antara lain :

Tahap pengaktifan pengetahuan yang sudah ada

Tahap ini dilakukan peneliti dengan mengadakan tes awal sebelum memulai pembelajaran yang bertujuan untuk melihat nilai yang diperoleh siswa sebelum mereka mempelajari materi yang diujikan tersebut dan membandingkannya dengan tes akhir. Mengawali pembelajaran guru mengadakan tanya jawab terhadap materi yang akan dipelajari, jawaban siswa merupakan landasan bagi guru untuk mengetahui pengetahuan atau konsep awal siswa terhadap materi. Tahap ini berjalan dengan baik karena banyak siswa yang ingin menjawab pertanyaan dari guru.

\section{Tahap pemerolehan pengetahuan baru}

Kegiatan pada tahap ini dilakukan dengan percobaan tentang konsep materi yang dipelajari siswa yaitu proses terjadinya erosi pada permukaan tanah. Percobaan dilakukan secara berkelompok, masing-masing kelompok beranggotakan 5 orang siswa. Sebelum kegiatan kelompok dimulai peneliti membagikan alat-alat percobaan dan LKS untuk panduan dalam kerja kelompok.

Kegiatan kelompok pada siklus I belum berjalan baik karena ada dua kelompok yang anggotanya bercampur siswa perempuan dan siswa laki-laki, hal ini menyebabkan siswa merasa malu untuk bergabung dalam kelompoknya. Selain itu, siswa belum terbiasa dalam belajar kelompok sehingga belum terjadi diskusi yang baik antara siswa. Kebanyakan siswa berebut untuk melakukan percobaan dalam kelompoknya, disinilah guru menjelaskan bahwa percobaan dilakukan secara bersama oleh anggota kelompok.

Setiap anggota kelompok mempunyai tugas dalam melakukan percobaan yaitu satu orang anggota kelompok memegang gelas yang dilubangi dan mengarahkannya pada masing-masing tanah, dua orang anggota kelompok menuangkan air pada gelas plastik yang di pegang temannya secara bersamaan, satu orang anggota kelompok menampung air yang dituangkan pada tanah berumput dan tidak berumput, dan satu orang anggota kelompok lagi mencatat waktu mulai menuangkan air dan kecepatan aliran air yang dituangkan.

Kelompok dalam melakukan percobaan kurang membaca LKS yang diberikan guru, sehingga peneliti harus memberikan bimbingan sepenuhnya untuk masing-masing kelompok. Untuk itu peneliti melakukan bimbingan secara klasikal sehingga proses percobaan berlangsung secara serentak oleh masing-masing kelompok. Selanjutnya kelompok mendiskusikan hasil percobaan yang telah dilakukannya dan menuliskan hasil diskusi kelompok pada LKS.

\section{Tahap pemahaman pengetahuan}

Tahap ini siswa mempresentasikan hasil diskusi kelompoknya ke depan kelas dan ditanggapi oleh kelompok lain. Berdasarkan tanggapan dari kelompok, siswa memperbaiki LKS. Melalui presentasi dan tanggapan dari kelompok siswa lebih memahami apa yang telah didiskusikannya dan dikuatkan lagi dengan arahan dari peneliti.

\section{Tahap menerapkan pengetahuan dan pengalaman yang diperoleh \\ Tahap ini peneliti melakukan tanya jawab tentang usaha yang akan dilakukan siswa agar erosi, banjir, abrasi, dan longsor tidak terjadi di lingkungannya. Peneliti memberikan bimbingan agar siswa dapat menerapkan usaha-usahanya menjaga lingkungan dalam kehidupan sehari-hari. Pada tahap inilah siswa merasakan bahwa materi yang dipelajarinya ada manfaatnya dalam kehidupan sehari-hari, sehingga siswa dapat menerapkan ilmu yang telah diperolehnya di sekolah.}

\section{Tahap refleksi}

Pada tahap refleksi ini peneliti masih mengadakan tanya jawab dan memberikan pengarahan tentang arti pentingnya menjaga 
lingkungan agar pengaruh erosi, abrasi, banjir, dan longsor tidak terlalu besar terhadap perubahan daratan. Serta dapat mencarikan solusi jika bencana alam yang lain terjadi, sehingga siswa dapat bertindak dengan baik dalam situasi yang berbeda.

Data hasil penelitian yang berkaitan dengan evaluasi pembelajaran perubahan lingkungan fisik dan pengaruhnya terhadap daratan, terungkap bahwa evaluasi yang dilakukan adalah evaluasi proses dan evaluasi hasil. Evaluasi proses pada setiap siklus dilakukan guru pada saat siswa berdiskusi dan hasil diskusi siswa. Evaluasi hasil dilakukan setelah pembelajaran berakhir.

Dalam pelaksanaan pembelajaran guru perlu memunculkan suasana belajar dengan cara kolaborasi/diskusi, baik dalam diskusi kelompok kecil maupun dalam kelompok besar. Adapun Belajar dengan kolaboratif secara langsung, dapat mendekatkan siswa pada ide situasi belajar yang diinginkan, membantu siswa kearah perkembangan kognitifnya dan mengantar siswa pada batas perkembangannya (Ritawati, 2001:164). Dengan kegiatan ini, siswa mampu berlatih dan berbagi pengalaman, melatih keberanian mengeluarkan pendapat, dan bersedia mendengarkan pendapat temannya.

Dari analisis penelitian siklus I nilai rata-rata kelas baru mencapai 6,96 dengan nilai tertinggi 8,75 dan 17 siswa mendapat nilai dibawah nilai 7 dari 40 orang jumlah siswa. Berdasarkan hasil pengamatan dan evaluasi pada siklus I yang diperoleh, maka direncanakan untuk melakukan perbaikan pada pembelajaran berikutnya atau selama proses pembelajaran pada siklus II. Pada siklus II nantinya guru memperhatikan kekurangankekurangan selama proses pembelajaran pada siklus I dan memperbaikinya pada siklus II.

\section{Pelaksanaan Siklus II}

Pembelajaran pencegahan kerusakan lingkungan pada siklus II ini berjalan dengan baik. Pada siklus II siswa sudah terbiasa dengan pembelajaran yang diberikan oleh guru. Pembelajaran sudah berjalan sesuai dengan perencanaan yang dibuat oleh guru. Pembelajaran berlangsung selama 4x35 menit dalam satu kali pertemuan.

Tahap pelaksanaan pembelajaran pada siklus II ini sama dengan langkah-langkah pada siklus I, perubahan dilakukan pada tahap pemerolehan pengetahuan baru adalah melalui penayangan video sehingga lebih menarik minat dan rasa ingin tahu siswa terhadap materi yang akan dipelajarinya. Perubahan juga dilakukan pada saat siswa berdiskusi kelompok tempat duduk siswa dibuat melingkar sehingga guru lebih mudah mengontrol kegiatan diskusi siswa. Dalam diskusi kelompok pada siklus II ini siswa sudah bisa bekerja sama dengan baik.

Kegiatan pembelajaran dengan pendekatan konstruktivis terdiri dari lima tahap antara lain:

Tahap pengaktifan pengetahuan yang sudah ada

Tahap ini dilakukan peneliti dengan mengadakan tes awal sebelum memulai pembelajaran yang bertujuan untuk melihat nilai yang diperoleh siswa sebelum mereka mempelajari materi yang diujikan tersebut dan membandingkannya dengan tes akhir. Mengawali pembelajaran guru mengadakan tanya jawab terhadap materi yang akan dipelajari yaitu cara pencegahan kerusakan lingkungan yang disebabkan oleh erosi, abrasi, banjir, dan longsor. Jawaban siswa merupakan landasan bagi guru untuk mengetahui pengetahuan atau konsep awal siswa terhadap materi. Tahap ini berjalan dengan baik karena siswa telah terbiasa dengan pembelajaran yang peneliti lakukan pada siklus I

\section{Tahap pemerolehan pengetahuan baru}

Kegiatan pada tahap ini dilakukan dengan mengamati tayangan video tentang cara pencegahan erosi. Pengamatan dilakukan oleh siswa pada tempat duduknya masingmasing. Siswa mencatat hal-hal penting dari hasil penayangan video. Siswa tampak termotivasi dalam mengamati penayangan video dan menunjukkan rasa ingin tahu yang tinggi terhadap isi tayangan video. Pembelajaran dengan memakai video lebih menarik minat siswa dalam belajar.

\section{Tahap pemahaman pengetahuan}

Pada tahap ini siswa duduk secara berkelompok dengan posisi melingkar agar memudahkan peneliti mengontrol kegiatan diskusi siswa, mendiskusikan tentang hasil penayangan video berdasarkan pengamatan anggota kelompok dan cara pencegahan kerusakan lingkungan lainnya seperti abrasi, banjir, dan longsor berdasarkan sumber yang diberikan peneliti. Untuk pemahaman pengetahuannya maka masing-masing kelompok mempresentasikan hasil diskusi kelompoknya ke depan kelas dan ditanggapi oleh kelompok lain. Berdasarkan tanggapan dari kelompok, siswa memperbaiki hasil 
diskusinya. Melalui presentasi dan tanggapan dari kelompok siswa lebih memahami apa yang telah didiskusikannya dan dikuatkan lagi dengan arahan dari peneliti.

Tahap menerapkan pengetahuan dan pengalaman yang diperoleh

Tahap ini peneliti memberikan penjelasan dan bimbingan supaya siswa dapat menerapkan cara pencegahan kerusakan lingkungan dalam kehidupannya sehari-hari, agar kerusakan lingkungan seperti yang diamatinya waktu penayangan video tidak terjadi pula di lingkungannya.

\section{Tahap refleksi}

Pada tahap refleksi ini peneliti masih mengadakan tanya jawab dan memberikan pengarahan tentang arti pentingnya menjaga lingkungan agar kerusakan lingkungan tidak terjadi di lingkungan tempat tinggal siswa.

Jumlah siswa kelas IV Sekolah Dasar Negeri 003 Bangkinang Kota adalah 40 orang, tetapi jumlah siswa yang hadir pada saat peneliti mengadakan pembelajaran siklus II adalah 38 orang.

Pelaksanaan evaluasi pada siklus II ini, peneliti memandu siswa dengan membacakan soal sebanyak dua kali untuk masing-masing soal dan siswa langsung menjawab soal yang dibacakan guru. Berdasarkan refleksi yang dilakukan pada akhir siklus II, terlihat kalau soal yang dibacakan guru lebih mudah dipahami oleh siswa.

Dari analisis penelitian siklus II nilai rata-rata kelas sudah mencapai 7,48 dan hanya 7 orang siswa yang mendapat nilai di bawah nilai 7. Berdasarkan hasil pengamatan siklus II yang diperoleh, maka hasil tindakan pada siklus II ini sudah mencapai target yang diinginkan dan peneliti sudah berhasil dalam usaha meningkatkan hasil belajar IPA kelas IV Sekolah Dasar Negeri 003 Bangkinang Kota dengan menerapkan pendekatan konstruktivis dalam pembelajaran.

\section{KESIMPULAN \& SARAN}

Berdasarkan uraian di atas maka dapat disimpulkan bahwa penerapan pendekatan konstruktivis dapat meningkatkan proses dan hasil belajar siswa pada mata pelajaran IPA di kelas IV SDN 003 Bangkinang Kota. Data penelitian menunjukkan bahwa terdapat peningkatan rata-rata hasil belajar siswa pada mata pelajaran IPA di kelas IV SDN 003 Bangkinang Kota.

\section{DAFTAR PUSTAKA}

Depdiknas. 2006. Kurikulum Tingkat Satuan Pendidikan. Jenjang Pendidikan Dasar. Jakarta: Depdiknas.

Ella Yulaelawati. 2004. Kurikulum dan Pembelajaran Filosofi Teori dan Aplikasi. Jakarta: Pakar Raya.

Maslichah Asy'ari. 2006. Penerapan Pendekatan Sains-TeknologiMasyarakat dalam Pembelajaran Sains di Sekolah Dasar. Yogyakarta: Universitas Sanata Dharma.

Miles, M. B. dan A. M. Huberman. 1992. Analisis Data Kualitatif : Buku Sumber tentang Metode-metode Baru. Terjemahan Tjetjep Rohindi Rohidi. UI Press: Jakarta.Tersedia dalam http:/www.blogger.com/feeds/8981256 $\underline{6507740045}$

20/posts/default/5187514118013731969

M. Ngalim Purwanto. 1996. Psikologi Pendidikan. Bandung: Remaja Rosdakarya.

Mohammad Amien. 1987. Mengajar IPA dengan Menggunakan Metode Discovery dan Inquiri. Jakarta: Dirjen Dikti.

Mohamad Nur. 2004. Pengajaran Berpusat kepada Siswa dan Pendekatan Konstruktivis dalam Pengajaran. Surabaya: Universitas Negeri Surabaya.

Nasution. 2003. Berbagai Pendekatan Dalam Proses Belajar Mengajar. Jakarta: Bumi Aksara.

Noraziah BT Ahmad. 2008. Konstruktivisme dalam Pengajaran dan Pembelajaran. Tersedia dalam http://www.geocities.com/azam60/tugas an 2ASAS.htm\#Konstruktivisme

Nurhadi, dkk. 2003. Pembelajaran Kontekstual dan Penerapannya dalam KBK. Malang: Universitas Negeri Malang.

Oemar Hamalik. 2008. Proses Belajar Mengajar. Jakarta: PT. Bumi Aksara.

Paul Suparno. 1996. Filsafat Konstruktivisme dalam Pendidikan. Yogyakarta: Kanisius.

Ritawati Mahyuddin. 2001. "Penggunaan Pendekatan Konstruktivisme dalam Pembelajaran Membaca Pemahaman 
Bagi Siswa Kelas V Sekolah Dasar Negeri Sumber Sari III Kec. Lowokwaru Kodya Malang." Tesis tidak diterbitkan. PPs-Universitas Negeri Malang.

Rochiati Wiriaatmaja. 2005. Metode Penelitian Tindakan Kelas: Bandung: PT. Remaja Rosdakarya.

Rustam Mundilarto. 2004. Penelitian Tindakan Kelas. Jakarta: Depdiknas. tersedia http://klinikpembelajaran.com/booklet/p enelitian tindakan kls.pdf. Suharsimi Arikunto. 2002. Prosedur Penelitian Suatu Pendekatan Praktek. Jakarta: PT. Rineka Cipta.

Supriyadi. 2005. Penelitian Tindakan Kelas. disajikan dalam Workshop MKKS Tingkat Pusat yang diselenggarakan oleh Direktorat Pendidikan Menengah Umum 12-15 September 2005 di hotel Evergreen, Cisarua, Bogor. Tersedia pada

http://akhmadsudrajad.wordpress.com/2 008/01/21/penelitian-tindakan-kelas.

Susanto. 2007. Pengembangan KTSP dengan Perspektif Manajemen Visi. Jakarta: Mata Pena.

Suwarsih Madya. Penelitian Tindakan Kelas. Tersedia pada http://www. ktiguru. org/index.php/ptk-I. Usman Samatawa. 2006. Bagaimana Membelajarkan IPA di SD. Jakarta: Depdiknas.

Wahyudin Nur Nasution. Efektivitas Strategi Pembelajaran Kooperatif dan Ekspositori terhadap Hasil Belajar Sains Ditinjau dari Cara Berpikir. Tersedia pada http://www.litagama.org/jurnal/edisi5/str ategipemb.htm.

Wina Sanjaya. 2006. Strategi Pembelajaran Berorientasi Standar Proses Pendidikan. Jakarta: Kencana Prenada Media Group. 